\title{
Climatic indicators regarding the rest period of sour cherry
}

\author{
Ladányi, M. ${ }^{1}$, Persely, Sz. ${ }^{2}$, Nyéki, J. ${ }^{3}$, Szabó, T. ${ }^{4}$, Soltész, M. ${ }^{3}$ \& Szabó, Z. $^{3}$ \\ ${ }^{1}$ Corvinus University of Budapest, Department of Mathematics and Informatics, \\ H-1118 Budapest, 29-43 Villányi, Hungary, E-mail: marta.ladanyi@uni-corvinus.hu \\ ${ }^{2}$ University of Debrecen, Centre for Agricultural Sciences and Engineering, Department of Economic Analysis \\ and Statistics, H-4032 Debrecen, 138 Böszörményi, Hungary, E-mail: suto@agr.unideb.hu \\ ${ }^{3}$ Institute for Research and Development, University of Debrecen, \\ H-4032 Debrecen, 138 Böszörményi, Hungary, E-mail: nyeki@agr.unideb.hu \\ ${ }^{4}$ Fruit Research and Extension Institute of Úffehértó, Hungary
}

\begin{abstract}
Summary: Sour cherry production in the world is increasing gradually. Profitable production, i.e. yield, depends largely on weather conditions. If Hungary wishes to keep up with the most successful countries, attention should be paid to the weather during the dormancy period, being definitely decisive from the points of view of quality as well as quantity. In order to predict the expected risk factors, characterisation of the most important weather parameters is necessary. For that purpose, the database of the Institute of Research and Extension Service for Fruit Growing at Újfehértó Ltd. has been utilised. Records of weather conditions were collected throughout the period 1984-2005, i.e. daily minimum, maximum and mean temperatures $\left({ }^{\circ} \mathrm{C}\right)$, and phenological diary of sour cherry varieties 'Újfehértói fürtös', 'Kántorjánosi' and 'Debreceni bőtermö'. For the future expectations study we have used the RegCM3.1 regional climate model with $10 \mathrm{~km}$ resolution. Data of 4 indicators have been traced: Average temperatures, Number of days without frost, Maximum length of periods without frost, Maximum length of frosty period. On the one hand, we surveyed the changes; on the other hand, estimates have been attempted for the future changes expected during the following decades.
\end{abstract}

Key words: regional climate model, indicator, sour cherry

\section{Introduction}

Sour cherry growing has traditions on the northern Hemisphere, in the cooler parts of the temperate zone, whereas its cultivation was initiated recently on the southern Hemisphere, too. In recent years yield of the world was about 1 million tons, $70 \%$ of which is produced in Europe. In 2005, Hungary had 16,692 hectares of sour cherry orchard which is $16 \%$ of the total orchard. $40 \%$ of the orchards are in the North Great Plain; nearly 32\% of orchards are in SzabolcsSzatmár-Bereg county. Orchards in Bács-Kiskun (32\%) and Pest $(15.3 \%)$ counties are also very important.

Sour cherry cultivation is limited by climatic risks (spring frosts, distribution of precipitation, drought, hails etc.) which threaten the economy of production. Beyond climatic risks the variation of prices and the mechanisms of the market (production, demands, prices) are the risks of the competitiveness. Global changes of climate endanger fruit production of the Great Plain region. Although temperatures in Hungary are prosperous for sour cherry, winter and spring frosts, drought and hails may cause occasionally heavy damages. The sour cherry cultivation is outstanding in the region of Szabolcs-Szatmár-Bereg county because growers, as a way of their further development, are interested in extending their horticultural production to have an alternative of apple, their main production. In this region $50-55 \%$ of Hungarian sour cherry production is concentrated. The climate is less hot and more humid than the southern part of the Plain, suitable for other fruits, too (apple, plum, walnut etc.). According to the Hungarian Central Statistical Office (HCSO), the majority (48\%) of new plantations was performed between 1995 and 1999, whereas the obsolete old plantations (before 1980) represent 7\%, only. A substantial part of orchards (28\%) are small with less than 0.5 ha extent and only $7 \%$ of the surface is represented by larger ( $>25$ ha) enterprises (HCSO).

The weather conditions influence differently the fruits grown, being variably susceptible to hazards appearing at various phases of the plant's development. With that purpose we examined first the weather conditions of the bloom period together with the 10-days-interval before bloom (Ladányi et al., 2010) and now the weather indicators of the rest period which have key effects on the quantity and quality of yield. The information on climatic indicators is inevitable to calculate the risks of fruit growing. We attempted to formulate the expected prediction of the chances in fruit production of the region. 


\section{Materials and methods}

General circulation models are usually validated for 100 $300 \mathrm{~km}$ resolution, therefore they do not fit to the studies of regional dimensions. For that purpose the global climatic models ought to be downscalled to small regions. One of the first regional climatic models, 'RegCM' has been modified from MM4 (Mesoscale Model) by the National Center for Atmospheric Research (NCAR) and the Pennsylvania State University (PSU) (Dickinson, 1989; Giorgi and Bates, 1989). Giorgi and his team (Giorgi, 1990) recognised that the predictions for short periods with regional models are suitable for learning the changes of regional climatic conditions. The models of limited domain require the definition of initial marginal conditions in order to trace their effects within the domain. With the development of the initial model RegCM2 was forwarded, which is based on the NCAR MM5 and CCM2 (Community Climate Model 2.). The first variant did not consider the effect of $\mathrm{H}_{2} \mathrm{O}, \mathrm{O}_{3}, \mathrm{O}_{2}$, $\mathrm{CO}_{2}$ and clouds, but the new variant averted this deficiency. In addition, another flux model has been used for the movement of clouds according to BATS1E. In case of RegCM3, the CCM3 has been utilised, which considered several greenhouse gases $\left(\mathrm{NO}_{2}, \mathrm{CH}_{4}, \mathrm{CFC}-\mathrm{s}\right)$, atmospheric aerosols and the ice crystals on a wide scale of clouds and precipitation formula.

For the purpose of examining the climatology of the rest period of sour cherry, we introduced indicators, artificial climatic parameters as functions of weather parameters, which proved to affect the plants. So the correlation with the response of plants are higher than that of the simple parameters. The analysis with the indicators supposes a sequence of years for a relatively long period, moreover, the quality of data is also decisive. The relevant literature reported the use of the method with the specific indicators of this kind (Bootsma et al., 2005a,b). Indicators can be used for field crops, fruit trees as well as for insects and vertebrate animals too (Erdélyi, 2009; Erdélyi et al., 2008; Koocheki et al., 2006; Salinger et al., 2005). As far as it is useful, we can consider mainly those specific indicators, which are most touched by the expected climatic changes for tracing the changes currently, moreover, we may predict the future changes (Carter et al., 2007). Information of this type predicts the chances and outlooks of the near as well as of far future and the risks expected in agricultural production. For our analysis the meteorological database of Research and Extension Service for Fruit Growing at Újfehértó Ltd. was available, with a series of data for the period 1984-2005 (daily minima, maxima and mean temperature). For the climatic changes, the team of Budapest University (ELTE) contributed with RegCM3.1 (regional) climate model downscallaed to a $10 \mathrm{~km}$ resolution (Bartholy et al., 2009; Torma et al., 2008).

Subsequently, we will present the climatic indicators of the rest period of sour cherry calculated for the time interval 1984-2005 and the expected parameters for the future period 2021-2050.

\section{Results}

\section{The indicators of the rest period}

The changes of daily mean temperature during the
rest period (from early October until end of March)

In Figure 1, left we can see the average of the daily mean temperatures of the rest period (October-March) for time interval 1984-2005. It was $2.7^{\circ} \mathrm{C}$ over the 22 years, the yearly variation was however conspicuous. In 1984, it was less than $1^{\circ} \mathrm{C}$, whereas in 1993 it was more than $4.5^{\circ} \mathrm{C}$. The estimations for the time interval 2021-2050 can be seen on the right side of Figure 1. The predicted mean value is $5^{\circ} \mathrm{C}$, which is an increment of more than $2^{\circ} \mathrm{C}$, compared with the earlier 22-year long period. In some years it may attain $7{ }^{\circ} \mathrm{C}$, in others $3.1{ }^{\circ} \mathrm{C}$, only. As a conclusion, in the near future a significantly increased mean temperature is expected in the rest period.

\section{The changes of the number of frost-free days during the rest period (October-March)}

A typical expression of stability during the rest period of sour cherry is the number of frost free days (when even the minimum temperature does not fall below $0^{\circ} \mathrm{C}$ threshold), the length of frost free periods, and the character of their appearance. If the periods are changing frequently, it may increase the risk, because the warm periods may induce growth and susceptibility to frost (Szabó, 2007). On the contrary, the chilling effect may delay the end of the rest period and the start of the spring season with dormant buds will lag. In Figure 2 the number of frost-free days is shown during the rest period. The mean of 22 years was 71 (Figure 2, left side). In 1995 and 2005, it was much less (50 and 40 days). In the future (2021-2050), the mean number of frost-free days is expected to be 102 (Figure 2, right side), varying between 90 and 110 days, which was earlier (1984-2005) 60 and 80 days.

\section{The maximum length of frost-free days during the rest period of sour cherry (early October - end of March)}

Between 1984 and 2005, the maximum length of frostfree periods was between 10 and 40 days (Figure 3, left). Outstanding values were in 1991 and 2000, with 63 and 62 days. In the series of 22 years, the mean was 26.5 days long. According to the climate model estimations, in the period 2021-2050 the length of frost-free period will increase with $90 \%$ probability to $40-80$ days (Figure 3 , right). The mean value is expected to be about 61.2 days.

\section{The maximum length of frosty periods during the rest period of sour cherry (early October - end of March)}

The maximum length of frosty periods in the past (19842005) was 31 days long (Figure 4, left). The yearly variation was large, in 2001 as many as 68 days, in 1993 and 1994 only 

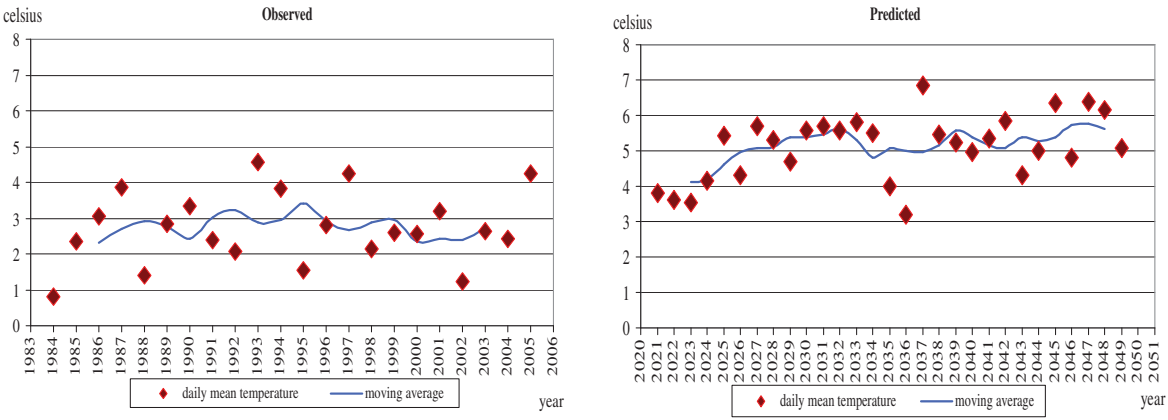

Figure 1. The average of the daily mean temperatures of the rest period of sour cherry (October-March) at Újfehértó, observed and calculated according to RegCM3.1
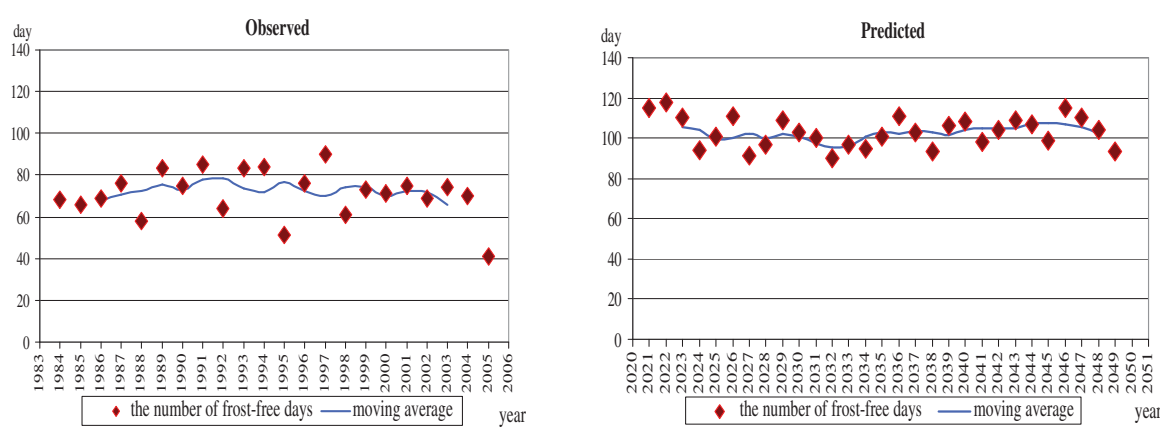

Figure 2. Number of frost-free days at Újfehértó in the past and estimated according to the model RegCM3.1 during the rest period of sour cherry (early October - end of March)
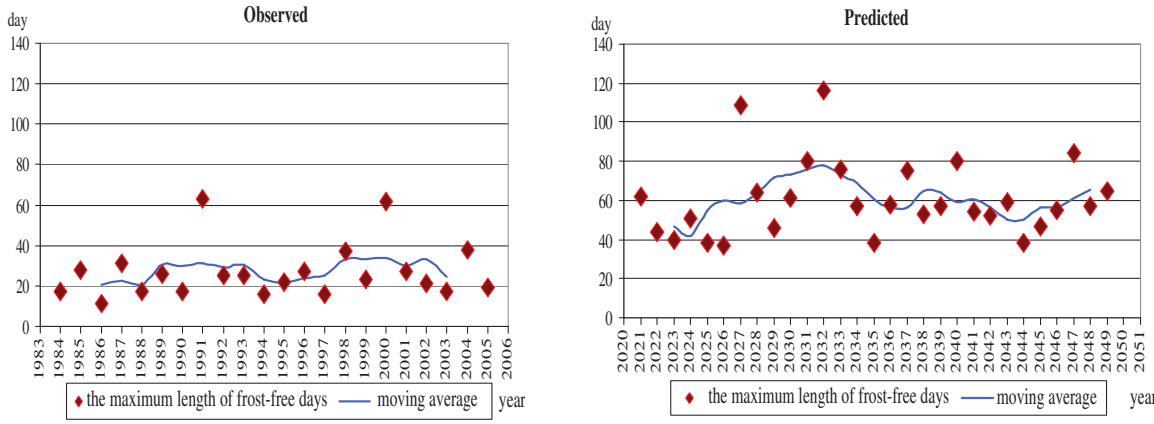

Figure 3. The maximum length of frost-free periods at Újfehérto in the past and according to the model RegCM3.1 during the rest period of sour cherry (early October - end of March)
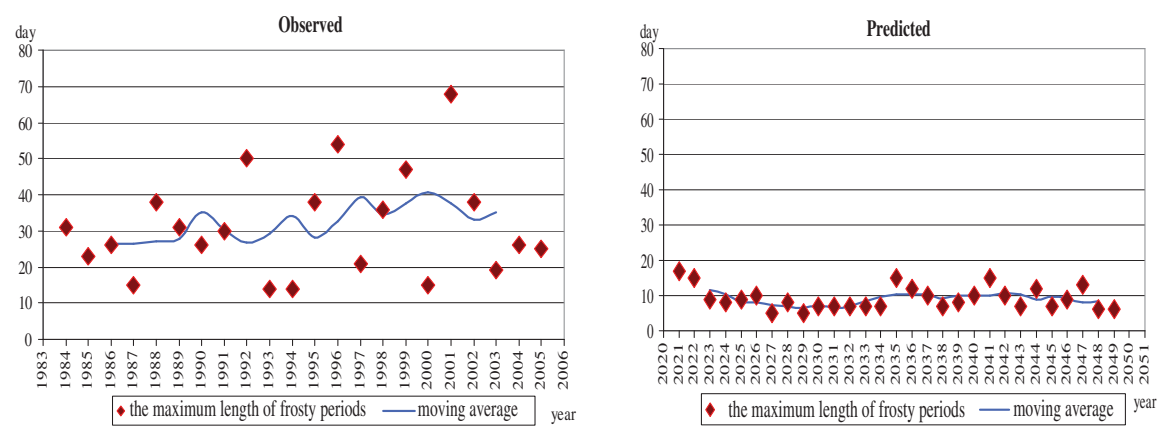

Figure 4. The maximum length of frosty periods at Újfehértó during the rest period of sour cherry (early October-end of March)
14 days were continuously frosty. According to the model RegCM3.1, in time slice 2021-2050, the mean of the maximum length of frosty periods is expected to be 9.5 days which varies between about 5 and 17 days length (Figure 4, right).

\section{Summary}

In our analysis, on the data basis of the Research Institute of Fruit Growing and Extension Service at Újfehértó Ltd., containing the daily mean, maximum and minimum temperatures in between 1984 and 2005, and utilising the RegCM3.1 climatic model, we concluded the following future expectations:

- During the rest period of sour cherry (early October- end of March) the average of the daily mean temperatures was $2.7^{\circ} \mathrm{C}$ in the time interval 1984-2005. According to the RegCM3.1 regional climate model it may be $5{ }^{\circ} \mathrm{C}$ as a mean between 2021 and 2050 , which is an increment of more than $2{ }^{\circ} \mathrm{C}$ which is significant.

- The mean number frost-free days was 71 in the past 22 years, which is expected to increase in the future to 102 days (2021-2050). The maximum length of frostfree periods was 26.5 days long, which is expected to increase to 61.2 days, according to the model RegCM3.1.

- The maximum length of frosty periods is expected to decrease from 31 days to about 9.5 days in the future.

The three climatic indicators above signalise the warming up of the climate, the reduction of the periods of frosty days as well as longer periods with frost-free days, which may reduce the risk of frost damage but will presumably risk the stability of the rest period by reducing the chance to satisfy the chilling requirement of the trees.

At the increasing costs of production and variable, often too low producer's prices, only high yields may secure a 
profitable production of sour cherry. From this point of view, the expected increasing mean temperature is not obviously beneficial especially in dormancy and if the precipitation will decrease, moreover, if the frequency and intensity of weather excesses increase. Conscientious of the facts, the strategies of adaptation to the expected changes ought to be planned.

\section{Acknowledgements}

The research was sponsored by the following projects: OM-00042/2008, OM-00265/2008, OM-00270/2008.

\section{References}

Bartholy, J., Pongracz, R., Torma, Cs., Pieczka, I., Kardos, P. \& Hunyady, A. (2009): Analysis of regional climate change modelling experiments for the Carpathian basin. International Journal of Global Warming, 1: 238-252.

Bootsma, A., Gameda, S. \& McKenney, D.W. (2005a): Impacts of potential climate change on selected agroclimatic indices in Atlantic Canada Canadian Journal of Soil Science, 85, (2): 329-343.

Bootsma A., Gameda S. \& McKenney D.W. (2005b) Potential impacts of climate change on corn, soybeans and barley yields in Atlantic Canada Canadian Journal of Soil Science, 85, (2): 345-357.

Carter, T. R., Parry, M. L. \& Porter, J. H. (2007): Climatic change and future agroclimatic potential in Europe. International Journal of Climatology, 11. (3): 251-269.

Dickinson, R. E., Errico, R. M., Giorgi, F. \& Bates, G. T. (1989) A regional climate model for the western United States, Climatic Change, 15: 383-422.

Hungarian Central Statistical Office (HCSO): Gyümölcs-, szőlő- és zöldségtermesztés, 2005.

Elguindi, N., Bi, X. Q., Giorgi, F., Nagarajan, B., Pal, J., Solmon, F., Rauscher, S.\& Zakey, A. (2007) RegCM Version 3.1 User's Guide. PWC/ICTP Internal Report, 57 pp.
Erdélyi, É. (2009): Sensitivity to Climate Change with Respect to Agriculture Production in Hungary (2009) Precision Agriculture '09 Edited by: E.J. van Henten, D. Goense and C. Lokhorst, Wageningen Academic Publisher, p. 559-567.

Erdélyi, É., Boksai, D. \& Ferenczy, A. (2008): Assessment of climate change impacts on corn and wheat in Hungary, 12th International Eco-Conference, 5th Eco Conference on Safe Food, Novi Sad (Serbia), 24-27 September, pp. 49-55.

Giorgi, F. (1990): Simulation of regional climate using a limited area model, nested in a general circulation model, Journal of Climate, 3: 941-963.

Giorgi, F. \& Bates, G. (1989): The climatological skill of a regional model over complex, Terrain, Montly weather review, 117: 2325-2347.

Giorgi, Marinucci, F. M., R. \& Bates, G. T. (1993) Development of a second generation regional climate model (RegCM2) i: Boundary layer and radiative transfer processes, Mon. Wea. Rev., 121: 2794-2813.

Koocheki, A., Nasiri, M., Kamali, G. A. \& Shahandeh, H. (2006) Potential impacts of climate change on agroclimatic indicators in Iran. Arid Land Research and Management, 20. (3): 245-259.

Ladányi, M. Persely, Sz., Szabó, T., Soltész, M., Nyéki, J. \& Szabó, Z. (2010) Climatic indicator analysis of blooming time for sour cherries. International Journal of Horticultural Sciences, 16 (1): 11-16.

Salinger, M. J., Sivakumar, M. V. K. \& Motha, R. (2005): Reducing vulnerability of agriculture and forestry to climate variability and change: Workshop summary and recommendations, Climatic Change, 70: 341-362.

Szabó, T. (2007): Az északkelet-magyarországi meggy tájfajta szelekció eredményei és gazdasági jelentősége. PhD értekezés, Budapesti Corvinus Egyetem

Torma, Cs., Bartholy, J., Pongracz, R., Barcza, Z., Coppola, E. \& Giorgi, F. (2008): Adaptation and validation of the RegCM3 climate model for the Carpathian Basin. Időjaras, 112: 233-247. 